\title{
UCLA
}

Mester

Title

Consonantal Variations in Chicano English

Permalink

https://escholarship.org/uc/item/0j63g0nx

Journal

Mester, 22(2)

Author

Ho, Joyce

Publication Date

1993

DOI

10.5070/M3222014267

Copyright Information

Copyright 1993 by the author(s). All rights reserved unless otherwise indicated. Contact the author(s) for any necessary permissions. Learn more at https://escholarship.org/terms

Peer reviewed 


\section{Consonantal Variations in Chicano English}

\section{Introduction}

Pronunciation is a prominent factor that clearly marks the differences found between varieties of a language. A series of investigations in this field concludes that during the learning of a second language, a new phonological system is derived different from the native language as well as the target language. Studies about the English spoken by Chicanos produced results that point at a structural consistency and temporal stability that forced many linguists to reconsider previously established theories about language interference. The English spoken by Chicanos is clearly distinctive; however, it lacks of many features that characterizes recent English learners.

The purpose of my paper will be to look at the variations of particular consonants at the syllable-building level in Chicano English. I shall focus on the interchange between the fricatives and the affricates palatals. I hope to bring a clear analysis of the roles of the consonants, in particular $\mathrm{B} / \mathrm{V}$ and $\mathrm{t} / \mathrm{S} / \mathrm{S}$, and the variations they undergo as they are first learned by an older generation of non-native speakers and later embraced as a first language by subsequent generations, thus producing a distinctive way of speech characteristic of an ethnic community. This paper is intended to be a "pilot study" that could lead to further investigation on this subject.

\section{Minimal Distinctions}

Marguerite MacDonald's article on The influence of Spanish Phonology on the English spoken by United States Hispanics is a comprehensive study of this interesting subject. Through out her article she provides detailed analysis that leads her to conclude that Hispanic English derives much of its phonologic identity from Spanish when minimal distinctions are involved. However, MacDonald readily points out that Spanish transfer must be supported by independent motivation. She highlights for us the multiple factors that must be taken into account. She strongly believes that "it is the reinforcement of the ancestral language phonology by 
multiple sources, including markedness, universality, first-language acquisition processes, and co-occurrence in the host-language varieties, which prolong restructuring in the interlanguage so that fossilization results" (MacDonald, p. 233) To this variation, she attributes the phonologic identity of the ethnic variety of English.

\section{The potential of Transfer}

MacDonald explains that Spanish and English share many of the same consonant phonemes. English, however, outnumbers Spanish in the category of fricatives. Many of the phonemes in these two languages may be identical but, they still may differ in phonetic realization and sequencing of segments. Looking at these differences MacDonald points out that the potential influence of the Spanish sound system on Hispanic English can be quite pronounced.

\section{Obstruents}

In this category, MacDonald produces the following conclusion:

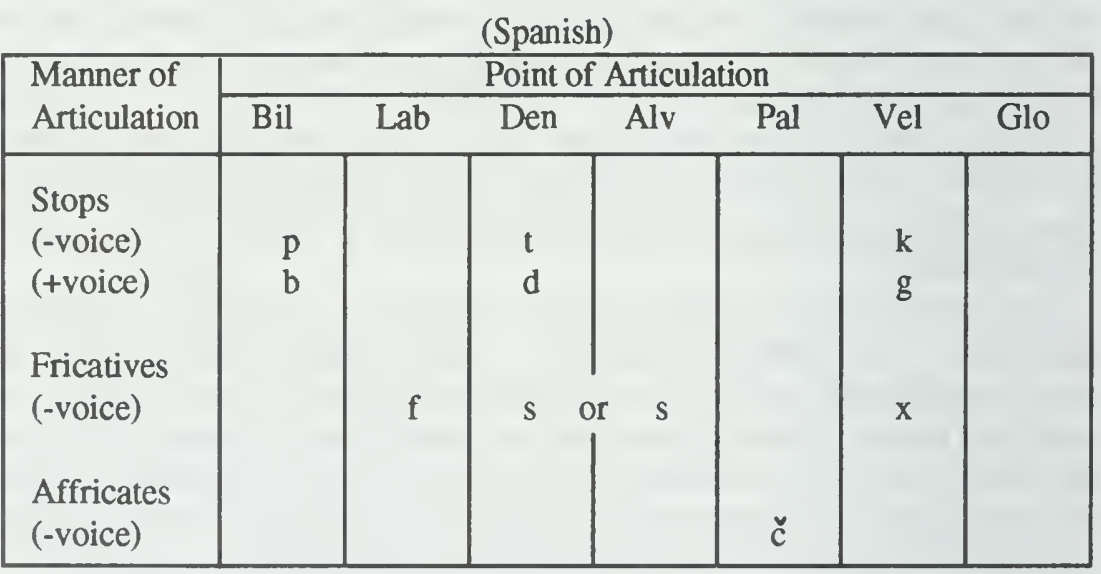

English

\begin{tabular}{|c|c|c|c|c|c|c|c|}
\hline & Bil & Labd & Inter & Alv & $\mathrm{Pal}$ & Vel & Glo \\
\hline $\begin{array}{l}\text { Stops } \\
\text { (-voice) } \\
\text { (+voice) }\end{array}$ & $\begin{array}{l}p \\
b\end{array}$ & & & $\begin{array}{l}\mathrm{t} \\
\mathrm{d}\end{array}$ & & $\begin{array}{l}\mathbf{k} \\
\mathrm{g}\end{array}$ & \\
\hline $\begin{array}{l}\text { Fricatives } \\
\text { (-voice) }\end{array}$ & & f & $\theta$ & s & š & & h \\
\hline $\begin{array}{l}\text { (+voice) } \\
\text { Affricates } \\
\text { (-voice) } \\
\text { (+voice) }\end{array}$ & & v & 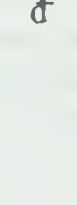 & Z & $\begin{array}{l}\check{c} \\
\check{j}\end{array}$ & & \\
\hline
\end{tabular}


In Spanish, the obstruents have one phonetic manifestation that is an unaspirated noncontinuant realization. They can occur in syllable-final position within a word and they do not occur in word-finally. Del Rosario (1970) and Guitart(1976) explain that even in syllable final, obstruents normally neutralize in point of articulation. In some cases they can be entirely deleted.

Example:

$$
\begin{aligned}
& \text { b } \quad \text { d } \quad \mathrm{g} \rightarrow \mathrm{b} \text { d } \mathrm{g} \text { /elsewhere } \\
& \text { [la tela] } \\
& \mathrm{b} \rightarrow \emptyset \mathrm{I} \_\mathrm{sC} \\
& \text { [tobstruent, -voice] } \\
& \text { [substrato] } \rightarrow \text { [sustrato] }
\end{aligned}
$$

In English, obstruents are aspirated in syllable-initial position preceding a stressed vowel. MacDonald points out that English obstruents can occur in onset or coda position syllable within a word or word-finally.

Example:

$\begin{array}{ll}\text { boxer } & \text { tub } \\ \text { cabbage } & \text { cab }\end{array}$

\section{Realization of $/ v /$ as $/ B /$ or $/ \not /$}

In the case of obstruents, MacDonald adds that in parts of Mexico, Cuba, Puerto Rico and the United States, /b/ frequently is realized as /v/. Penfield and OrnsteinGalicia (1985) in their study show that among Chicano English speakers it is difficult at times to distinguish $\mathrm{a} / \mathrm{v} /$ from $\mathrm{a} / \mathrm{b} /$. While conducting my own study with Los Angeles Chicanos I also noticed that with words such as 'level', 'invited' and 'vacation', many of the speakers often pronounced them as: lebel, inbited and bacation. This leads me to believe that some Chicano English speakers were simply applying the Spanish phonemic realization of / $/$ for both the orthographic $/ \mathrm{b} /$ and $/ v /$. This would seem that the interchange of $/ \mathrm{b} /$ and $/ \mathrm{v} /$ is most likely a case of transfer.

\section{Arguments against interference}

The idea of interference or transfer has often lead Chicano English to be characterized as poorly spoken English. Penfield and Ornstein-Galicia point out that it was not until 1970 that new light was shed on this subject. While observing and studying Chicano English, researchers began to question whether the concept of interference was really that appropriate. Garland Bills (1977) argue the following: "But the speech of very many Chicanos appears to exhibit clear signs of temporal stability, structural consistency, and internal (not just external) predict- 
ability. In other words, it seems to represent a systematically distinct competence -a dialect. (Penfield \& Ornstein, p. 34)"

One of Bills' main arguments against interference, which is also the focus of my paper, is the fact that many linguistics aspects of Chicano Eng lish are not predictable when we contrast and compare Spanish and English. At the phonologic level, Bill brings to our attention the particular uses of 'tš' and 'š' as an example to confirm the fact that the argument of interference is no longer valid. He points out that among

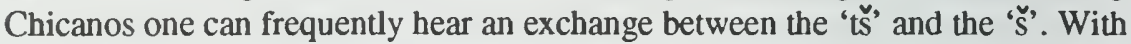
words like 'Check' one hears 'Sheck' or 'Sheynsh' for change. With these examples, Bill concludes that "a contrastive analysis of Spanish and English would predict the opposite, since most dialects of Spanish do not even have the š sound". (Penfield \& Ornstein, p. 34)

\section{Alternation of tš and š}

Among linguists, there are several debates trying to explain the free substitution of the tš for the š and vice-versa. One of the two main theories in this field is the process of merger proposed by Ornstein. The other theory, the process of unmerger is proposed by Wald. Ornstein believes that these two sounds are being confused because they are actually merging. The result we are obtaining is actually varying degrees of these two phonemes. Wald, on the other hand, claims the exact opposite. He believes that tš and š are in the process of being distinguished thus, at times, they are confused. Still others believe that the alternation of tš and šs is simply due to confusion.

Opposing arguments like these led to a more careful look at standard Spanish and English. In standard Spanish š sound does not exist. The interference explanation does not apply here because it could not explain the reason for words pronounced "sheck" when it clearly required a tš sound. Further investigations suggested that sociolinguistic factor must be taken into account. One finds such alternation of tš and š not only among Chicanos but also in Spanish of non-English speakers along the border. Such a case leads Penfield and Ornstein to question, "does this suggest that language contact with English has permeated even the monolingual Spanish-speaking community or is there a possibility that this speech trait represents contact with regional varieties of Spanish which do indeed have this pronunciation?"(Penfield \& Ornstein, p. 40)

Although an answer has not yet been found, many linguists have resorted to universal linguistic tendencies to explain such a case. The result is the following, "while most languages of the world which have tš also have sh, the reverse is not true." (Penfield \& Ornstein, p. 40) This means that languages that have the tš sound will have the tendency to produce its counterpart, the š sound. Such an explanation would account for the alternation of tš and š in Chicano English. 


\section{Discussion of traits}

In my interest to develop a better understanding of the alternation of consonants such as ts and s, I begin my investigation by looking at its segmental structure with the help of Katamba's book An introduction to Phonology.

At the segmental structure ts and $s$ are described as follows:

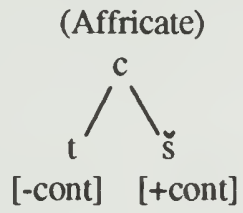

Relevant trait to distinguish tš from š is:

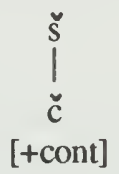

From this segmental structure of tš, I proceed to look at its syllable building level. A word such as 'Chicago' is described as follow:

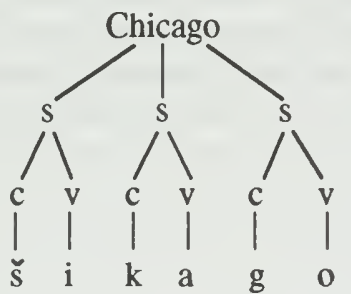

\section{Methods}

Three subjects were enrolled in this study ( 2 female and 1 male). All subjects were born in the Los Angeles area and were between the ages of 20-25.

Subjects were then asked to read a reading sample that contains words that exhibit Chicano English variation. (Appendix 1) These words were presented in a paragraph and as individual words. The paragraph was used to demonstrate any variation that may occur in a context of narrating a text. The individual words were used to test if such variation was influenced by the position of the consonant in a given word or phrases. 


\section{Results}

From the data gathered above, the following results can be ascertained. In words such as chapel and bachelor, using the $\mathrm{CV}$ phonology model the results are as follows:

\section{Word: Chapel}

Alternation from $\mathrm{ts} \longrightarrow \check{s}$

\section{Standard English}

\section{Chicano English}
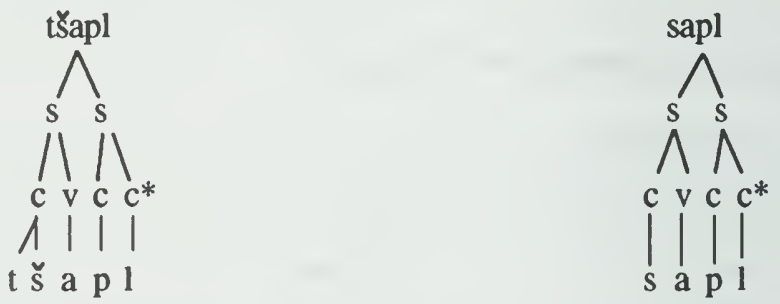

c* syllabic nucleus

From the above model, we observe that in standard English (StE) the onset is branching while in Chicano English (ChE) the onset becomes non-branching. We exhibit a simplification of the onset that seems inclined to maintain the model CV (canonical syllable).

Word: Bachelor

Alternation from $t \check{\text { š }} \rightarrow$ š

StE

ChE
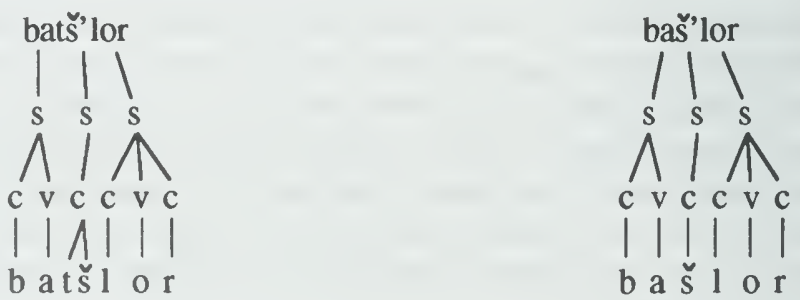

In $\mathrm{StE}$ the rhyme is branching while in $\mathrm{ChE}$, the rhyme becomes non-branching. 
In $\mathrm{ChE}$ the rhyme is simplified. This example shows that such a simplification can occur both at the onset and at the rhyme.

Word: Shoes

Alternation from $\breve{s} \rightarrow$ ť

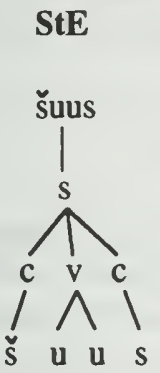

\section{ChE}

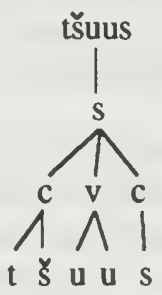

In $\mathrm{StE}$ the onset exhibits no branching while in $\mathrm{ChE}$ we observe the opposite effect. This phenomenon might at first lead one to believe that the alternation of ts

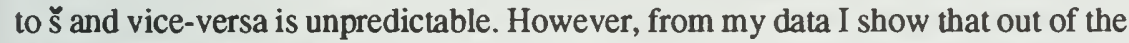
sample words provided in my survey, the alternation from ts to $\zeta$ was by far more frequent than the alternation from $\zeta$ to $t \zeta$. The frequency of $t \zeta \longrightarrow \zeta$ over $\zeta \longrightarrow t \zeta$ alternation is $4: 1$. The data obtained seems to reaffirm what Universal Linguists have pointed out. If a language already has the tš sound, it will likely adopt it counterpart, the š sound; however, the reverse is not necessarilly true. The fact that some $\mathrm{ChE}$ speakers actually do alternate $̌$ with tšalthough infrequently, only makes us realize that there are multi-causal factors that are not always phonologically based.

\section{Some tendencies}

In the to to $\zeta$ alternation we observe that such changes are associated with particular vowels. From the list of words below, it can be ascertained that ts tends to change to š when located near a [-high] vowel.

Words:

Bachelor
Impeachment
Check
Chapel$$
\text { tš } \rightarrow \text { š __v; \#_ }
$$$$
\text { [-high, ] }
$$

As for the š to tš alternation the following is derived: 
Words:

Chicago

Shoes

Sheriff

$$
\check{\mathrm{s}} \longrightarrow \mathrm{t} \breve{s} / \text { - } ; \text {; \# }
$$

[-low]

Since the $s$ to ts alternation is rather infrequent, although with its due tendency, I continue to look at some sociolinguistic effects that need to be addressed in order to see the complexity of the matter at hand.

\section{Sociolinguistic Effects}

Marguerite MacDonald (1989) and many other linguists attribute these observable variations in $\mathrm{ChE}$ to several factors that merit further study. MacDonald presents the many factors that contribute to variations in a language that often are overlooked in research. I shall summarize her observations in the following list:

1) Age

2) Gender

3) Choice of language spoken at home

4) Socioeconomic differences and job status

5) Education

6) Personal factors

MacDonald explains that the age at which children begin to learn English and/ or Spanish does affect the acuteness of their hearing and their ability to discern sounds. Men and women due to cultural background do receive unequal exposure to languages. Men because of their involvement in a labor force tend to be bilingual. And as for the socioeconomic differences and education, these factors have tremendous impact on language variations.

I distinguish the personal factor in particular because in my investigation I noticed that the personality of my informants had a strong effect on their speech. Some informants were self-conscious when speaking English. They would speak softly and when they encountered words that they felt uncomfortable pronouncing, they often said them quickly. Although I can see the effect this has in language variability, it is very difficult to research and study.

\section{Conclusion}

Evidently, there are phonologic differences between Chicano English and standard English. However, it is no longer adequate to assume that the characteristics of Chicano English are a consequence of Spanish, even when it exhibits variations from the monolingual English community. Clearly there are forces at work to accentuate these differences, but most importantly, there are observable tendencies that show that there is a distinct competence. With respect to the consonantal variation there is yet no microanalysis done in this aspect. Hopefully 
until much more extensive work is done, it will continue to be the subject of much attention and debate.

Joyce Ho

University of California, Los Angeles

\section{Appendix 1: Reading Sample}

To plan for my brother's bachelor party I went to an ATM machine to get some cash.

(bašelor)

For the bachelor party, I'm preparing his favorite dish which is chicken.

The party was great until someone poured a bottle of whisky into the fruit punch. People started pushing each other and many of my bookshelves fell.

The house was such a mess, much of the decoration was trashed.

$$
\text { (muš) }
$$

Because of the incident at the bachelor's party, many of his friends didn't show up at the chapel.

(šapel)

After organizing the bachelor party I went on a long vacation.

(bacašion)

-Michigan
-machine
-shampoo
*chapel
*check
-a chair
+shoes
-punch
-bashful

* Alternation from tš to š

- Do not exhibit any variation

+ Alternation from $\breve{s}$ to $t \check{s}$

+Chicago
*bachelor
-cash
*impeachment
*poaching
*a chimney
-sheets
*such
-cashier

+Chicago

*bachelor

cash

*impeachment

poaching

-sheets

-cashier 


\section{WORKS CITED}

Bjarkman, P. \& Hammond, R. M.American Spanish Pronunciation. Washington: Georgetown University Press, 1989.

Katamba, F. An introduction to Phonology. New York: Longman, 1989.

Ornstein-Galicia, Jabob. Form and function in Chicano English. Massachusetts: Newbury House Publishers Inc., 1981.

Penfield, Joyce \& Ornstein-Galicia, Jacob. Chicano English: An ethnic contact dialect. Pbiladelphia: John Benjamins Publishing Company, 1985. 